\title{
Genetic Diversity, Cytogenetics, and Biomass Yields among Taxa of Giant Reeds (Arundo Species)
}

\author{
Darren H. Touchell ${ }^{3,4}$, Thomas G. Ranney ${ }^{1}$, and Dilip R. Panthee ${ }^{2}$ \\ Department of Horticulture Science, Mountain Horticultural Crops Research and Extension Center, \\ North Carolina State University, 455 Research Drive, Mills River, NC 28759-3423 \\ Ronald J. Gehl \\ Department of Soil Science, Mountain Horticultural Crops Research and Extension Center, North \\ Carolina State University, Mills River, NC 28759-342; and DuPont Pioneer, 3801 Peachtree Circle, \\ Manhattan KS 66503-9807
}

\begin{abstract}
Alexander Krings
Department of Plant Biology, North Carolina State University, 2115 Gardner Hall, Box 7612, Raleigh, NC 27695-7612
\end{abstract}

\begin{abstract}
Additional INDEX words. bioenergy, chromosome number, DNA content, genome size, polyploidy
Abstract. Genetic diversity and cytogenetics of 31 accessions of Arundo L., collected from North America and South Asia, were characterized using 20 intersimple sequence repeat (ISSR) markers, flow cytometry, and cytology. In addition, field trials of 23 Arundo donax L. accessions were established in 2011 and harvested in 2012 to 2013 to assess annual biomass yields. Cluster analysis, based on Jaccard's similarity coefficient method, clearly differentiated Arundo formasana Hack. from A. donax and a third unidentified Arundo taxon. Arundo donax further contained two subgroups representing North American (naturalized and cultivated) and South Asian collections. Within each $A$. donax subgroup, genetic distances were very low (0.03 for North America and 0.07 for South Asia). Principle coordinate analysis further supported distinct clusters. Relative genome sizes were determined using Pisum sativum L. as the reference genome and 6-diamidino-2-phenylindole (DAPI) fluorochrome. Chromosome numbers (2n), ploidy levels, and $2 \mathrm{C}$ relative genome sizes ranged from $\approx 62$ to 105 , near $12 x$ to near $18 x$, and 2.78 to $4.13 \mathrm{pg}$, respectively, and were similar within each taxa/subgroup. While there was a low level of genetic variability among $A$. donax accession, dry biomass yields varied significantly ranging from 6.5 to $65 \mathrm{Mg} \cdot \mathrm{ha}^{-1}$ per year for the third growing season.
\end{abstract}

Arundo species are perennial rhizomatous grass belonging to the tribe Arundinae (subfamily Arundinoideae: Poaceae) (Barker et al., 1999). Arundo donax, in particular, is one of the largest of the herbaceous grasses (Perdue, 1958), growing in dense clumps and attaining heights of up to 8-9 $\mathrm{m}$ (Lewandowski et al., 2003). With such impressive growth rates, $A$. donax is a leading candidate for cultivated biomass in Mediterranean climates (Angelini et al., 2009; Cosentino et al., 2006) and is also being considered as an energy crop in North America (Gilbert at al., 2008; Lewandowski et al., 2003). Many of the advantages of $A$. donax as an energy crop include a high yield potential (up to $63.1 \mathrm{Mg} \cdot \mathrm{ha}^{-1}$ of dry matter), high lignin and cellulose content, rapid growth rate (up to $0.7 \mathrm{~m} \cdot \mathrm{week}^{-1}$ under favorable conditions), high carbon sequestration, widely adaptable

Received for publication 25 Sept. 2015. Accepted for publication 19 Feb. 2016. We thank BP Biofuels North America, the Biofuels Center of North Carolina, and the North Carolina Department of Agriculture and Consumer Services for financial support.

We also gratefully acknowledge the technical assistance of Mitch Sewell, Thomas Eaker, Nathan Lynch, Jeremy Smith, Hem Paudel, Nathan Ranney, and the staff at the Mountain Horticultural Crops Research Station, as well as Drs. Paul M. Peterson and Rob Soreng (United States) who aided in specimen identification, and William Anderson for sharing germplasm included in this study.

${ }^{1}$ JC Raulston Distinguished Professor.

${ }^{2}$ Associate Professor.

${ }^{3}$ Research Scholar.

${ }^{4}$ Corresponding author. E-mail: darren_touchell@ncsu.edu. to marginal sites, low irrigation and nutrient requirements, and minimal soil tillage, (Lewandowski et al., 2003).

Arundo donax is generally found in alluvial, riparian habitats, such as along the borders of lakes or ditches, but can tolerate a wide range of diverse ecological conditions (Perdue, 1958; Vollmer et al., 2008). The native origin of $A$. donax has been variously reported as southern Asia (Bell, 1997; Dudley, 2000), eastern Asia (Polunin and Huxley, 1987), and countries surrounding the Mediterranean Sea (Perdue, 1958), though a recent study has provided evidence that $A$. donax likely originated in Asia and subsequently spread into the Mediterranean region (Mariani et al., 2010). A. donax also has been widely dispersed by humans throughout subtropical and warm-temperate regions for diverse applications including musical instruments, paper and pulp, and woven baskets (Perdue, 1958). In North America, A. donax was introduced into southern California in the early 1800s for erosion control with latter introductions being made in Texas and Florida as late as the 1940s (Bell, 1997; Perdue, 1958). Since its introduction, giant reed has been widely cultivated in North America and has escaped cultivation in some areas (Perdue, 1958).

Genetic diversity is important for the selection, cultivation, and potential breeding of $A$. donax with desirable traits including high biomass yields, resistance to pest and diseases, and regional adaptability. Unfortunately, a low level of genetic diversity has been reported for $A$. donax in southern North America and southern Europe (Ahmad et al., 2008; Hardion 
et al., 2012; Khudamrongsawat et al., 2004; Lewandowski et al., 2003; Mariani et al., 2010; Pilu et al., 2014). For example, the $\mathrm{G}: \mathrm{N}$ ratio of unique genotypes $(\mathrm{G}=$ unique genotypes and $\mathrm{N}=$ samples) was 0.050 in France and 0.011 in the United States (Ahmad et al., 2008), and ranged from 0.083 to 0.093 in two studies in Italy (Mariani et al., 2010; Pilu et al., 2014). However, Khudamrongsawat et al. (2004) reported a G:N ratio of 0.41 indicating a more moderate level of genetic diversity in 97 accessions collected from eight populations along the Santa Ana River in southern California. The low level of genetic diversity for A. donax in Europe and the United States has been attributed to its lack of sexual reproduction and limited diversity in founding introductions. Reproduction of A. donax is almost exclusively asexual by clonal spread by rhizome extension and by aquatic dispersal of rhizomes and stem fragments (Johnson et al., 2006; Mariani et al., 2010; Perdue, 1958). A. donax has shown a very limited capacity to produce viable seed attributed to early gamtetophytic failure (Hardion et al., 2015).

Despite the relative lack of genetic diversity within $A$. donax, Cosentino et al. (2006) reported significant levels of variation in biomass yield among accessions in field trials in southern Italy. For example, the aboveground 2nd year biomass yield of clones from 39 different populations ranged from 14.9 to $34.2 \mathrm{Mg} \cdot \mathrm{ha}^{-1}$ per year of dry matter, with an average of $22.1 \mathrm{Mg} \cdot \mathrm{ha}^{-1}$ per year. Expanding germplasm collections with accessions from other areas, particularly Asia, may capture greater genetic diversity.

The base chromosome number for Arundo has been reported as $x=6$ or 12 (Hardion et al., 2011, 2013; Lewandowski et al., 2003). This confusion arises due to the high chromosome numbers resulting from multiple whole genome duplication events (Connor and Dawson, 1993, and discussed in Christopher and Abraham, 1971). However, Hardion et al. $(2011,2013,2014)$ concluded $x=6$ seemed to be the most suitable theoretical base number based on cytology of Arundinoideae and related taxa. Several cytotypes have been reported ranging from $2 n=12 x(\approx 72)$ to $2 n=18 x(\approx 108)$ (Bucci et al., 2013; Christopher and Abraham, 1971; Haddadchi et al., 2013).

Although there is limited genetic diversity within North American and southern European A. donax, there is evidence for substantial differences in yield between genotypes. Further, there has been no characterization of wild collected Arundo from South Asia. Thus, the objective of this study was to evaluate genetic diversity, cytogenetics (ploidy, chromosome numbers, and relative genome sizes) and biomass yields of Arundo taxa collected from North America and South Asia, to identify candidate genotypes for future development of North American bioenergy feedstocks.

\section{Materials and Methods}

Plant materials. Thirty-one accessions of Arundo species were collected from native, naturalized and/or cultivated areas in the United States, India, and Nepal (Table 1). Identification of all taxa was based on morphology and confirmed using the following herbaria: GH (Harvard University, Cambridge, MA), L/U (National Herbarium Nederland, Leiden and Utrecht, The Netherlands), NCSC (North Carolina State University, Raleigh, NC), P (Museum National d'Histoire Naturelle, Paris, France), and U.S. (Smithsonian Institution, Washington, DC).
DNA Extraction. Total genomic DNA was extracted from $300 \mathrm{mg}$ of leaf tissue taken from newly expanded shoots. Tissue was homogenized in a mortar and pestle with $2 \mathrm{~mL}$ extraction buffer and a spatula -tip of sterilized sand, and incubated at $65{ }^{\circ} \mathrm{C}$ for $1 \mathrm{~h}$. Extraction buffer consisted of: 10 parts modified cetyltrimethylammonium bromide (CTAB) buffer (1\% CTAB, $0.7 \mathrm{M} \mathrm{NaCl}, 100 \mathrm{~mm}$ Tris- $\mathrm{HCl} \mathrm{pH} 8.0,15 \mathrm{~mm}$ ethylenediaminetetraacetic acid (EDTA) pH 8.0, 0.2 м sorbitol, 2\% polyvinylpyrrolidone); 2 parts 5\% sarkosyl; and supplemented with $0.25 \%$ sodium bisulfite. These three components were mixed together before extraction. The supernatant was extracted with one volume phenol:chloroform:isoamylalcohol $(24: 24: 1, \mathrm{v} / \mathrm{v})$, and again with chloroform:isoamylalcohol $(24: 1, \mathrm{v} / \mathrm{v})$. The DNA was precipitated with one volume isopropanol at $-20{ }^{\circ} \mathrm{C}$ for $1 \mathrm{~h}$, washed with one volume $70 \%$ ethanol, and again with $100 \%$ ethanol. The pelleted DNA was air-dried and resuspended in $500 \mathrm{~mL}$ of sterile Tris EDTA (TE). Because of the polysaccharide- and polyphenolic-rich tissue of these grasses, the DNA was reextracted, precipitated with one volume $100 \%$ ethanol and 0.1 volume $3 \mathrm{M}$ ammonium acetate at $-20{ }^{\circ} \mathrm{C}$ for $30 \mathrm{~min}$, air-dried and resuspended in $100 \mathrm{~mL} \mathrm{TE}$, and stored at $4{ }^{\circ} \mathrm{C}$ (short term) or $-20^{\circ} \mathrm{C}$ (long term). Quantity and quality of DNA was assessed using a spectrophotometer (NanoDrop 2000; Thermo Scientific, Wilmington, DE).

ISSR-POLYMERASE CHAIN REACTION (PCR) ANALYSIS. Twenty ISSR primers were identified and selected from those found to be commonly successful for grasses (Table 2). Nineteen of the primers were a dinucleotide repeat $(8 \times)$ with a 1 or 2-bp 3' anchor. The remaining primer was a tetranucleotide repeat $(4 \times)$ without an anchor. The PCR reaction mixture $(10 \mu \mathrm{L})$ consisted of $2.5 \mathrm{ng}$ DNA, $0.6 \mu \mathrm{M}$ ISSR primer and $5 \mathrm{uL}$ 2X GoTaq ${ }^{\circledR}$ Green Master Mix (Promega, Madison, WI). PCR amplifications were performed using a modified touchdown procedure (Don et al., 1991; Hecker and Roux, 1996), based on the melting temperature $\left(T_{\mathrm{m}}\right)$ for each individual primer. PCR parameters consisted of: 1) an initial denaturation step ( 7 min at $\left.94^{\circ} \mathrm{C}\right)$; 2) a total of 40 amplification cycles consisting of three steps each with five different modified touchdown annealing temperatures, $T_{\mathrm{a}}(i)$, where $\left.i=1-5 ; 2 \mathrm{a}\right)$ denaturation $(30 \mathrm{~s}$ at $\left.94{ }^{\circ} \mathrm{C}\right) ; 2 \mathrm{~b}$ ) annealing [30 s at $\left.T_{\mathrm{a}}(i)\right]$, where $T_{\mathrm{a}}(1)=T_{\mathrm{m}}+4^{\circ} \mathrm{C}$ for the first three cycles, $T_{\mathrm{a}}(2)=T_{\mathrm{m}}+2{ }^{\circ} \mathrm{C}$ for cycles $4-6, T_{\mathrm{a}}(3)=$ $T_{\mathrm{m}}$ for cycles $7-10, T_{\mathrm{a}}(4)=T_{\mathrm{m}}-2{ }^{\circ} \mathrm{C}$ for cycles $11-14$, and $T_{\mathrm{a}}$ (5) $=T_{\mathrm{m}}-4{ }^{\circ} \mathrm{C}$ for cycles $\left.15-40 ; 2 \mathrm{c}\right)$ extension $\left(70 \mathrm{~s}\right.$ at $\left.72{ }^{\circ} \mathrm{C}\right)$; 3) a final extension step $\left(7 \mathrm{~min}\right.$ at $\left.72^{\circ} \mathrm{C}\right)$. PCR amplifications were performed using a thermocycler (Master Gradient; Eppendorf, Hauppauge, NY). The amplified products and a 100-bp DNA ladder (Phenix Research Products, Candler, NC) were electrophoresed on ice at $100 \mathrm{~V}$ for $2.5 \mathrm{~h}$ on a $1.5 \%$ agarose gel $(0.5 \times$ Tris base/Boric acid/EDTA buffer), stained in EtBr solution $\left(0.5 \mu \mathrm{g} \cdot \mathrm{mL}^{-1}\right)$ and digitally photographed under ultraviolet light.

ISSR DATA ANALYSIS. Digital photographs of each ISSR amplification were visually scored for the presence (1) or absence (0) of individual bands for each accession. Only the most distinguishable and reproducible bands were scored and used for analysis. Estimates of genetic similarity were calculated for the 31 accessions using Jaccard coefficient of similarity. A visual representation of the association between accessions were obtained from the data matrix using unweighted pair-group methods using arithmetic averages and principal coordinate analysis (PCoA) and were performed by using NTSYS-PC software (Rohlf, 1989). In addition, a frequency down weighted (DW) measure marker values measure 
Table 1. Arundo species collected in North America and South Asia, accession codes and collection region with corresponding genome sizes, chromosome numbers, and ploidy levels.

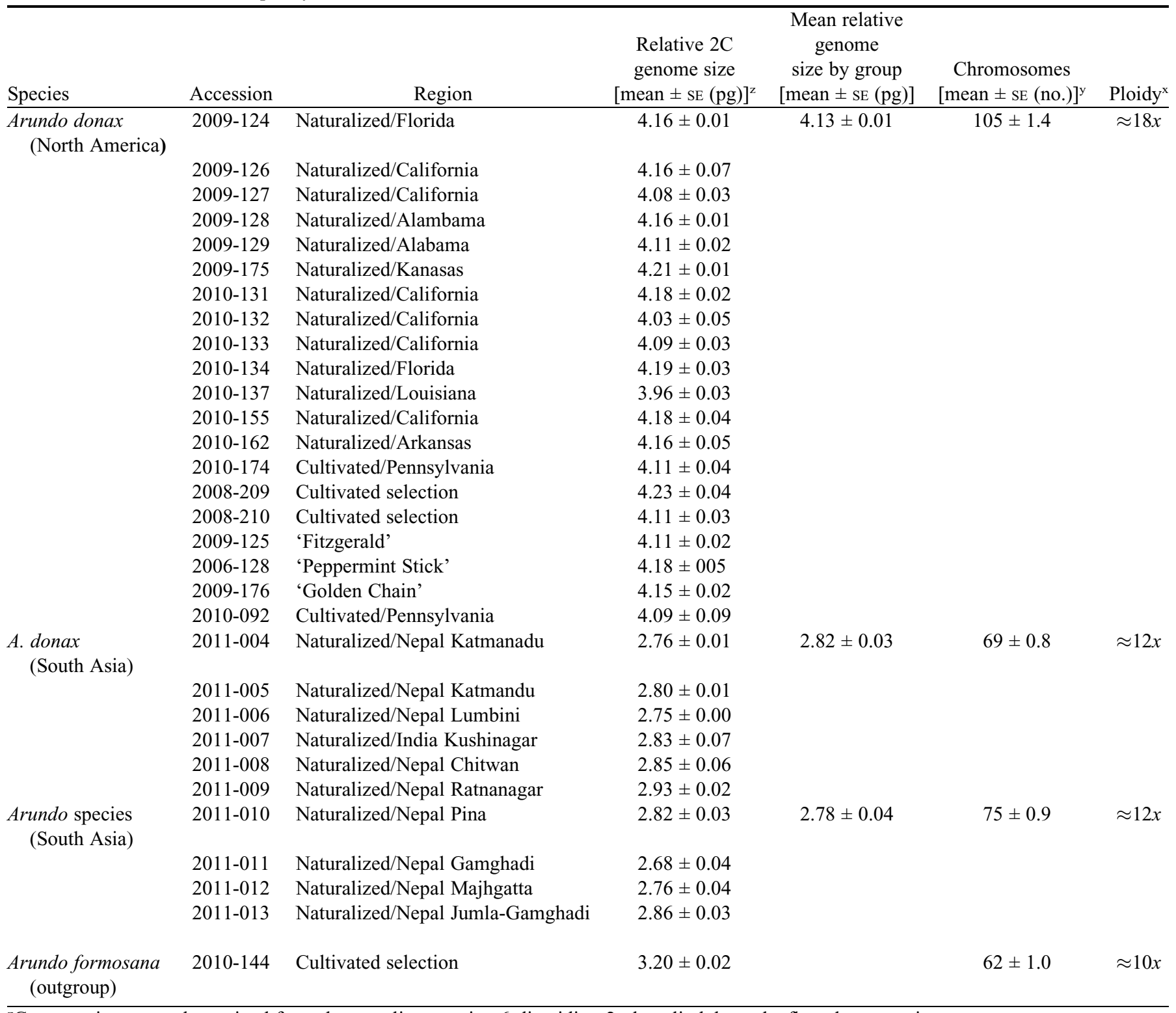

${ }^{\mathrm{z}}$ Genome sizes were determined from three replicates using 6-diamidino-2-phenylindole as the flurochrome stain.

${ }^{\mathrm{y}}$ Chromosome counts were performed on an individual from each group and were the mean from at least five cells.

xPloidy level was based on $x=6$.

of divergence was calculated. For each distinct lineage, the number of occurrences of each ISSR marker in that lineage was divided by the number of occurrences of that particular marker in the dataset and values were summed. The value of DW should be high in long-term populations and low in newly established populations, thereby distinguishing old variance from more recently established populations (Schönswetter and Tribsch, 2005).

Cytogenetics. Flow cytometry was conducted on fresh tissue $\left(\approx 0.5 \mathrm{~cm}^{2}\right)$ taken from recently expanded leaves with two subsamples from each accession. Leaf tissue from the samples was combined with an internal standard ( $P$. sativum 'Ctirad', $2 \mathrm{C} \mathrm{DNA}=8.76 \mathrm{pg}$ ) and finely diced with a razor blade in a petri dish containing $400 \mu \mathrm{L}$ of nuclei extraction buffer (CyStain ultraviolet Precise P Nuclei Extraction Buffer; Partec, Münster, Germany). The nuclei extract was filtered into a small test tube using a $50-\mu \mathrm{m}$ filter and a staining solution containing $1.6 \mathrm{~mL}$ DAPI buffer (CyStain ultraviolet Precise P Staining Buffer, Partec) was added. Samples were refrigerated at $4{ }^{\circ} \mathrm{C}$ for $1 \mathrm{~h}$. A flow cytometer (PA-I; Partec) was used to analyze the stained nuclei with a minimum of 3000 counts per sample. Holoploid, $2 \mathrm{C}$ genome size was calculated as: $2 \mathrm{C}=$ genome size of standard $\times$ (mean fluorescence value of sample/mean fluorescence value of standard).

Cytology was conducted on an individual accession from each subgroup, determined in the phylogenetic analyses. Actively growing root tips $(\approx 5 \mathrm{~mm})$ were excised from plants and placed into a solution of $2 \mathrm{~mm} 8$-hydroxyquinoline and $70 \mathrm{mg} \cdot \mathrm{L}^{-1}$ cyclohexamide. Root tips were incubated for $2 \mathrm{~h}$ in dark at room temperature followed by $2 \mathrm{~h}$ in dark at $4{ }^{\circ} \mathrm{C}$ and then rinsed in cold distilled $\mathrm{H}_{2} \mathrm{O}$, blotted dry, and fixed in $95 \%$ ethanol: propionic acid $(3: 1, \mathrm{v} / \mathrm{v})$ for 16 to $24 \mathrm{~h}$ at room temperature. 
Table 2. Inter simple sequence repeat (ISSR) primer composition, number of polymorphic and unique fragments, and down weighted (DW) measure marker values for each Arundo species group.

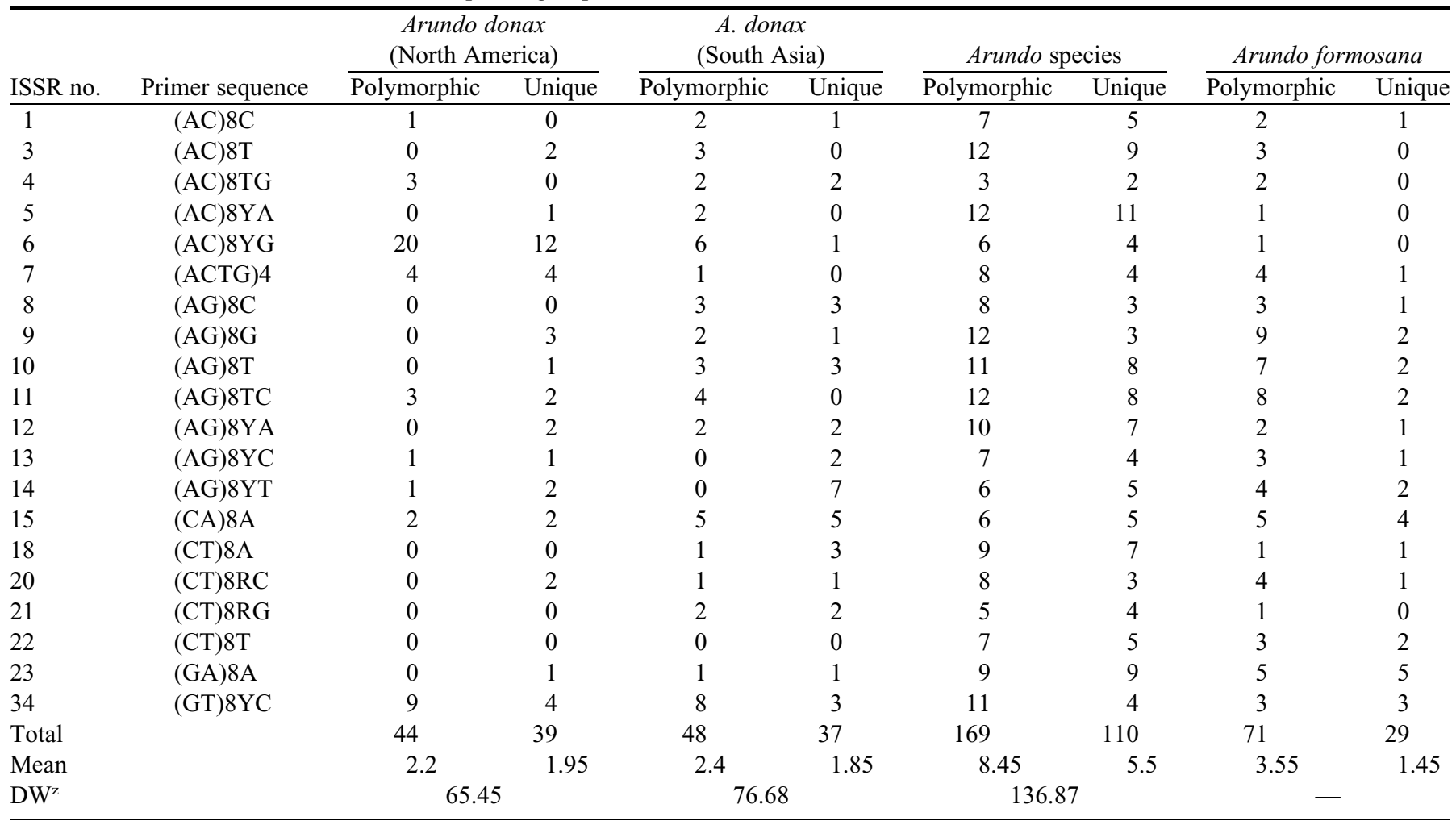

${ }^{\mathrm{z}}$ Down weighted measure marker values measure of divergence was calculated for each distinct lineage. The number of occurrences of each ISSR marker in a distinct lineage was divided by the number of occurrences of that particular marker in the dataset and values were summed.

Root tissue was rinsed with and stored in $70 \%$ ethanol at $4{ }^{\circ} \mathrm{C}$. Root tissue was hydrolyzed in 95\% ethanol : $12 \mathrm{~N} \mathrm{HCl} \mathrm{(3:1,}$ $\mathrm{v} / \mathrm{v}$ ) for 5 to $20 \mathrm{~s}$, depending on root diameter. Root tissue was placed on a microscope slide and the extreme root tip was excised. A drop of modified carbol fuschin stain (Kao, 1975) was added. The excised root tip was gently squashed with a coverslip. Chromosomes were counted using oil immersion at $\times 1500$. Because of the difficulty in clearly discerning large numbers of chromosomes accurately, counts were determined for at least five cells for each plant and presented as a mean \pm SE.

FiELd ESTABLISHMENT AND BIOMASS YIELD. Field trials were established for $23 \mathrm{~A}$. donax accessions at the Mountain Horticultural Crops Research Station, Mills River, NC. Plants were propagated from canes (nodal explants) and grown in 18-cell trays. Yield trials were planted in May 2011 (with the exception of accession 2010-174 that was planted in Aug. 2011) with plots arranged in a randomized complete design with three replicates (blocks). Each plot was $2 \times 5 \mathrm{~m}$ and contained 18 plants in three rows, with plants spaced $1 \mathrm{~m}$ apart. Plots were separated by $2-\mathrm{m}$-wide alleys and received overhead irrigation, as needed, for the first 3 months of establishment following planting. Nitrogen was applied as ammonium nitrate $\left(33.5 \% \mathrm{~N}\right.$, mass basis) annually at a rate of $68 \mathrm{~kg} \cdot \mathrm{ha}^{-1}$, in the spring before shoot emergence. Soils were a Bradson gravelly loam, clayey, parasequic, mesic Typic Hapludults. Soil samples were collected at the time of planting and were analyzed by the North Carolina Department of Agriculture and Consumer Services Agronomic Division (NCDA\&CS) soil testing laboratory. Soil $\mathrm{pH}$ was 5.8 , humic matter was $0.36 \%$, cation exchange capacity (CEC) was $5.9 \mathrm{mmol} \cdot \mathrm{kg}^{-1}$, Ca was $52 \%$ of CEC, $\mathrm{Mg}$ was $22 \%$ of $C E C$, and $\mathrm{P}, \mathrm{K}$, and $\mathrm{S}$ were all within recommended levels based NCDA\&CS indices for perennial grasses. Temperature and precipitation data were obtained from a weather station at the site and compiled by the North Carolina Climate Retrieval and Observations Network of the Southeast database (Table 3). Data for the 30-year temperature and precipitation were obtained from the National Oceanic and Atmospheric Administration (Table 3).

Biomass yield was determined annually from harvests in late December after stands had gone dormant. The center six plants from each plot were harvested $10 \mathrm{~cm}$ above the ground and weighed fresh. An $\approx 1 \mathrm{~kg}$ subsample was selected from each plot, ground, and weighed to obtain fresh weight. Subsamples were then oven dried at $80{ }^{\circ} \mathrm{C}$ for $72 \mathrm{~h}$ and reweighed to determine dry weight and to calculate moisture content and dry biomass yields. Data analysis was conducted using a mixed linear model with repeated measures SAS PROC MIXED (SAS version 9.4; SAS Institute, Cary, NC). Accessions and years were treated as fixed-effect parameters while blocks were treated as random-effects parameter. Means were separated by Scheffes's multiple comparison test using.

\section{Results and Discussion}

Phylogeny and systematics. The 20 ISSR primers yielded 330 polymorphic bands. Each ISSR primer generated from 12 to 28 (mean, 22.9) bands, and fragment sizes ranged from 170 to 3000 bp. A total of $39,37,110$, and 29 bands $(73.6 \%)$ were 
Table 3. Monthly precipitation totals and mean temperatures for 2011, 2012, and 2013 and the long-term average (1981-2010) at Mills River, NC. ${ }^{\mathrm{z}}$

\begin{tabular}{|c|c|c|c|c|c|c|c|c|}
\hline \multirow[b]{3}{*}{ Month } & \multicolumn{4}{|c|}{ Precipitation $(\mathrm{mm})$} & \multicolumn{4}{|c|}{ Temp $\left({ }^{\circ} \mathrm{C}\right)$} \\
\hline & & & & $30-\mathrm{yr}$ & & & & $30-\mathrm{yr}$ \\
\hline & 2011 & 2012 & 2013 & mean & 2011 & 2012 & 2013 & mean \\
\hline January & 38 & 102 & 231 & 106 & 0.2 & 4.4 & 5.4 & 2.1 \\
\hline February & 69 & 38 & 100 & 104 & 5.7 & 6.4 & 3.8 & 3.9 \\
\hline March & 173 & 86 & 94 & 112 & 8.5 & 12.6 & 4.9 & 7.7 \\
\hline April & 114 & 117 & 159 & 92 & 14.8 & 14.0 & 12.7 & 12.3 \\
\hline May & 89 & 86 & 212 & 103 & 17.2 & 18.6 & 16.1 & 16.9 \\
\hline June & 88 & 43 & 294 & 129 & 21.5 & 20.6 & 21.2 & 21.1 \\
\hline July & 128 & 125 & 428 & 121 & 23.6 & 23.4 & 22.0 & 22.9 \\
\hline August & 82 & 62 & 233 & 127 & 22.6 & 21.1 & 21.1 & 22.6 \\
\hline September & 92 & 140 & 86 & 110 & 18.3 & 18.5 & 18.6 & 18.8 \\
\hline October & 63 & 87 & 63 & 81 & 11.3 & 12.1 & 13.6 & 13.0 \\
\hline November & 126 & 22 & 106 & 98 & 8.5 & 6.1 & 5.8 & 8.1 \\
\hline December & 132 & 114 & 220 & 103 & 5.9 & 5.9 & -1.0 & 5.1 \\
\hline $\begin{array}{l}\text { Total }(\mathrm{mm}) \text { or } \\
\text { average }\left({ }^{\circ} \mathrm{C}\right)\end{array}$ & 1,012 & 1,022 & 2,226 & 1,287 & 12.1 & 13.6 & 12.0 & 12.7 \\
\hline
\end{tabular}

${ }^{\mathrm{z}}$ National Oceanic and Atmospheric Administration (2010).

unique to the $A$.donax (North America), A. donax (South Asia) Arundo species (South Asia), and the Arundo formosana outgroup, respectively (Table 2), with a 127 polymorphic bands between taxa.

Results from the cluster analysis clearly distinguish $A$. donax from $A$. formosana and a third unidentified Arundo taxon from South Asia (Fig. 1). A. donax was further divided into two subgroups representing plants collect from either North America or South Asia.

The results from PCoA provided strong support of cluster analysis groupings (Fig. 2). Accessions of $A$. donax were clustered in two geographically distinct groups with small variability within each group. The unidentified Arundo taxon from Asia was distantly related to both $A$. donax groups, whereas $A$. formasana was intermediate.

The relationships between the subgroups within each species are reflected by the genetic distant coeffecients (Table 4). In all cases, the within-group genetic distance was considerably lower than the among-group genetic distance and provided further support for the cohesion within, and separation among, the subgroups identified in cluster and PCoA analyses.

The taxonomy of Arundo remains unresolved (Hardion et al., 2012). At present, $A$. donax serves as a broadly applied name encompassing entities exhibiting considerable morphological variation, particularly in Asia (Hardion et al., 2014). It is highly likely that multiple taxa worthy of recognition may be subsumed under this species designation. The unidentified Arundo species in this study was collected in Nepal and appeared distinct from $A$. donax, but not consistent with currently recognized species in that region. A broader systematic study is required to clarify the taxonomy and proper nomenclature of this taxon.

Genetic Diversity Within $\boldsymbol{A}$. DONAX. Of the total markers that were polymorphic among all taxa, 45.8\% (151/330) were polymorphic within the $A$. donax. The remaining $54.2 \%$ were either present $(9.7 \%)$, or absent $(44.5 \%)$, in every accession within this group. Considering only those markers that were polymorphic within the $A$. donax group, $83.4 \%$ (126/151) were unique to either the North American (42.3\%) or South Asian
(41.1\%) subgroups. The remaining $16.6 \%$ were present in both subgroups. Forty-four markers were polymorphic within the North American subgroup and 48 within the South Asian (Table 2).

The genetic distance estimates were recalculated using only those markers that were polymorphic within the A. donax group, and within its two subgroups to attain a more representative estimation of the genetic diversity found within the $A$. donax collection. Considering the $A$. donax group as a whole, the average distance within the group was 0.23 and among subgroups was 0.53. Considering the North American and South Asian subgroups individually, the lowest pairwise genetic distance within North American and South Asian subgroups was 0.01 (2008-209/2009-124/2009-127 and 2006-128/2009$125)$ and 0.01 (2011-005/2011-007), respectively, and the highest was 0.07 (2010-131/2010-137) and 0.14 (2011-005/ 2011-009), respectively. The average distance within each subgroup was 0.03 and 0.07 , respectively. A relatively small number of the ISSR primers generated the polymorphisms that were used to distinguish each accession by a unique genotypic profile (e.g., only four of the 20 ISSR primers amplified $75 \%$ of the polymorphic markers within the North American A. donax, while only nine primers amplified $100 \%$ of the polymorphic markers). In addition, the DW ranged from 65.45 in North American population to 136.87 in Arundo species from South Asia, supporting lower variability in North America. The variation detected among the South Asian accessions fell along two discernable phylogenetic lines, while those among the North American accessions revealed no apparent phylogenetic association (Fig. 1). Similarly, Hardion et al. (2014) found two distinct lineages with biogeographical structuring, with the first morphotype corresponding to A. donax from the Middle East and Mediterranean and a second Himalayan morphotype.

These results indicate a low level of genetic variability among the accessions, both within and between the A. donax subgroups. A total of 21 distinguishable genotypes were identified with a $\mathrm{G}: \mathrm{N}$ proportion of 0.81 (where $\mathrm{G}=$ number of genotypes and $\mathrm{N}=$ number of samples). Several previous studies have found similar results (Ahmad et al., 2008; Haddadchi et al., 2013; Hardion et al., 2012, 2014, 2013; Khudamrongsawat et al., 2004; Mariani et al., 2010; Pilu et al., 2014). For example, Haddadchi et al. (2013) found a similar G:N proportion (0.83) in 58 samples of $A$. donax collected from 15 naturalized populations in eastern Australia, using 30 ISSR markers. Hardion et al. (2012, 2014) also found limited genetic diversity for $A$. donax in the Mediterranean area; however, their studies also revealed higher level of variation among accessions from Asia.

Cytogenetics. Mean relative $2 \mathrm{C}$ genome sizes for $A$. donax (North America), A. donax (South Asia), Arundo species (South Asia), and $A$. formosana were $4.13,2.82,2.78$, and $3.20 \mathrm{pg}$, respectively (Table 1). Relative genome sizes for individual plants within these groups were consistent and provided further support for the groups and subgroups identified from the cluster analysis. Cytology conducted on a representative plant from each group/subgroup, showed variation in chromosome numbers (ploidy levels) among groups including $\approx 62(\approx 10 x)$ for A. formosana, $\approx 69(\approx 12 x)$ for A. donax (South Asia), $\approx 75(\approx 12 x)$ for Arundo species (South Asia), and $\approx 105(\approx 18 x)$ for A. donax (North America), assuming $x=6$.

Ploidy levels of Arundo species (Table 1) varied among the subgroups identified from the ISSR cluster analysis (Fig. 1). 


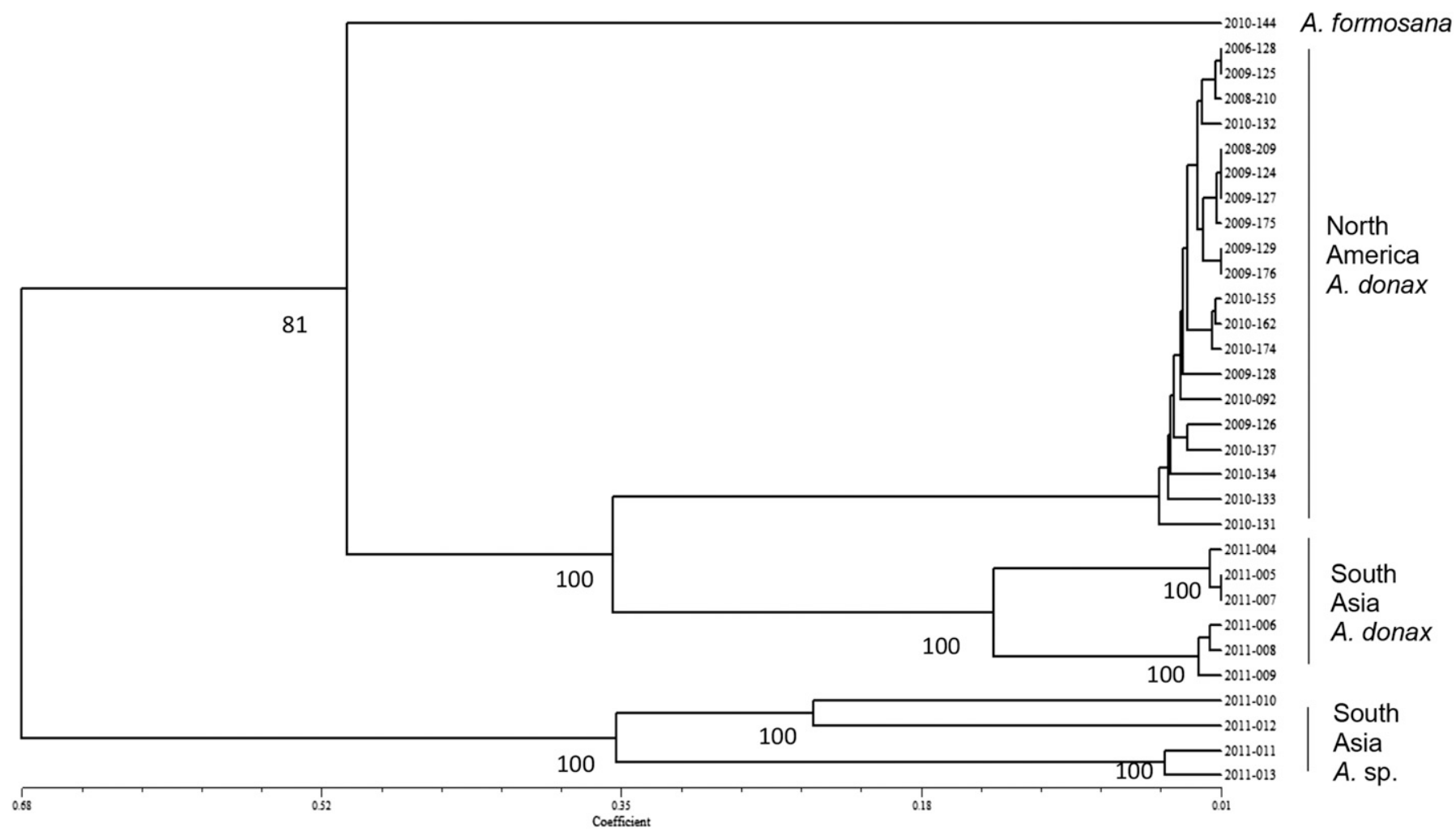

Fig. 1. Dendrogram derived from unweighted pair-group methods using arithmetic averages cluster analysis based on Jaccard's index of similarity indicating the relatedness of 31 accessions of Arundo sp. The bootstrap values as determined as percentage of 100 trees are given at the branches greater than $50 \%$. The dendrogram was constructed using NTSYS (Rohlf, 1989).

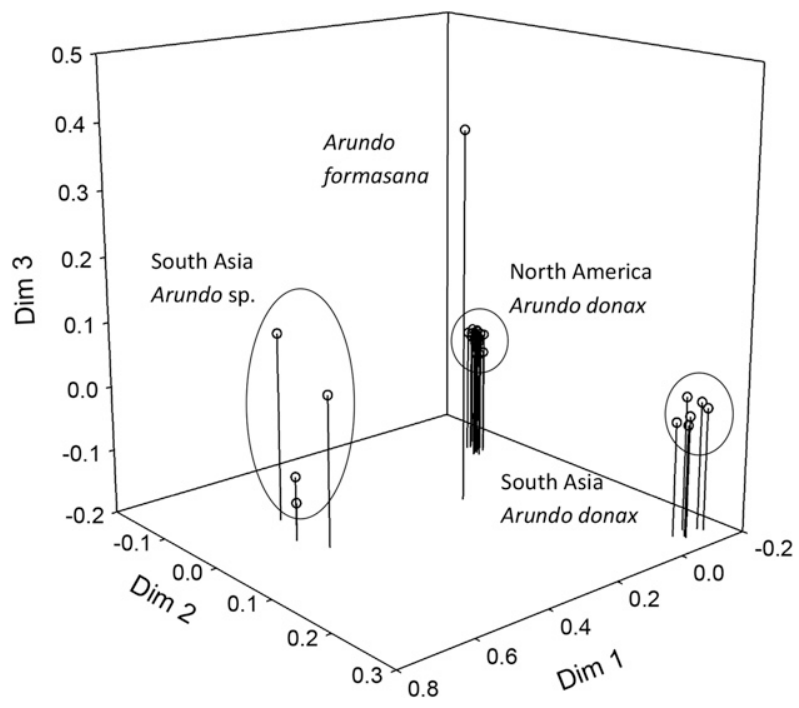

Fig. 2. Principal coordinate analysis of 31 accessions of Arundo species resulting from analysis of 330 inter simple sequence repeat bands. Percentage of variance attributed to Dimension $1 \%$ to $66.3 \%$, Dimension $2 \%$ to $25.7 \%$, Dimension $3 \%$ to $8.0 \%$. Analysis was performed using NTSYS (Rohlf, 1989).

The North American A. donax had an approximate chromosome number of $2 n=105$ (aneuploid, near enneaploid), similar to that reported by Hardion et al. (2013) and Bucci et al. (2013) for $A$. donax with $2 n=110$. Further, genome sizes from $A$. donax samples collected from Egypt were consistent with those observed for North American accessions (D.H. Touchell, data
Table 4. Matrix of genetic distance (Nei and Li, 1979) within (italicized) and between subgroups within Arundo species collected in North America (NA) and South Asia (SA).

\begin{tabular}{lcccc}
\hline & $\begin{array}{c}\text { Arundo } \\
\text { formasana }\end{array}$ & $\begin{array}{c}\text { NA: Arundo } \\
\text { donax }\end{array}$ & $\begin{array}{c}\text { SA: } A \text {. } \\
\text { donax }\end{array}$ & $\begin{array}{c}\text { SA: } \text { Arundo } \\
\text { species }\end{array}$ \\
\hline A. formasana & 0 & & & \\
NA: A. donax & 0.49 & 0.03 & & \\
SA: A. donax & 0.54 & 0.35 & 0.07 & \\
SA: Arundo species & 0.62 & 0.67 & 0.73 & 0.17 \\
\hline
\end{tabular}

not presented), providing support that North American $A$. donax was introduced from the Mediterranean. Further, in our study A. donax from the putative center of origin in South Asia was estimated to be a near dodecaploid (Table 1). Interestingly, A. donax in Australia was reported to have $2 n=84$ (Haddadchi et al., 2013) further indicating sources of genetic diversity.

The nonreduction of chromosomes during meiosis (i.e., during sexual reproduction) is thought to be the primary means of chromosome doubling and thereby achieving higher levels of ploidy (Parisod et al., 2010). However, Les and Philbrick (1993) have suggested that with many aquatic angiosperms (characterized by clonal growth, high vagility of vegetative propagules, and rare sexual reproduction, which also typifies A. donax), somatic doubling of chromosomes during mitosis, followed by asexual reproduction, is likely the primary mode of polyploidization. However, higher ploidal levels can also complicate fertility, where the formation of multivalents can produce irregular chromosome segregation and unbalanced gametes, as observed in both male and female haploid 


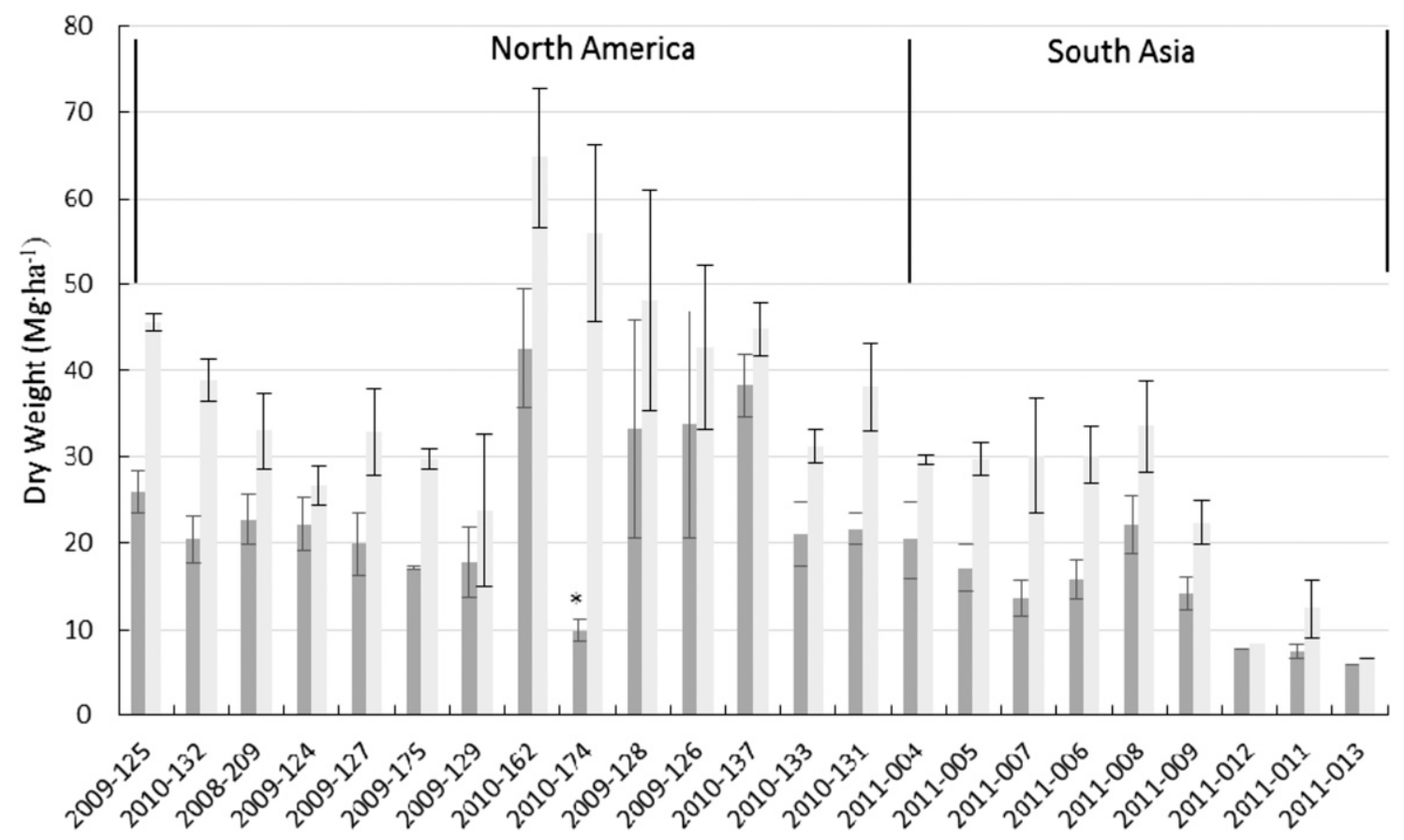

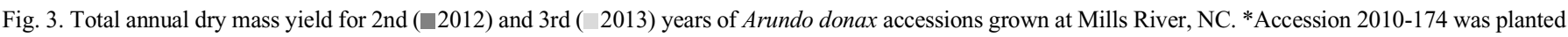
Aug. 2011 and did not have a complete first growing season. Biomass yield is the mean of three replicates \pm SE.

gametophytic development of $A$. donax (Hardion et al., 2015; Mariani et al., 2010). While early gametophytic failure likely causes sterility in A. donax, it is not certain if infertility arose first, followed by polyploidization through somatic doubling, or if infertility followed the development of higher ploidy levels. Indeed related taxa, Arundo plinii Turra pollen viability was high for both $2 n=72=12 x$ and $2 n=108=18 x$ cytotypes (Hardion et al., 2015). Further seed development was observed in the $12 x$ cytotype suggesting, other mechanisms may also contribute to sterility (Hardion et al., 2015).

Novel polyploid cytotypes may coexist with progenitor cytotypes, potentially replace the progenitor cytotypes as a result of a competitive advantage, or diverge into new niches as a result of ecotypic differentiation (Thompson and Lumaret, 1992). For A donax morphological differences have been reported for different cytotypes. For example, the Mediterranean $18 x$ cytotype is larger, more vigorous and has significantly larger stomatal guard cells than the $12 x$ sino-Himalayan cytotype (Hardion et al., 2014). However, Hardion et al. (2014) noted that differences in ploidy do not necessarily result in ecotypic differentiation. For example, although $12 x$ and $18 x$ cytotypes exhibited different morphologies, evidence suggests they were intermingled within the same habitat (Hardion et al., 2014). However, ploidy for $A$. donax sampled in our study were segregated by location. Hardion et al. (2014) suggested it is likely the robust $18 x$ cytotype was dispersed by humans from southeast Asia to the Mediterranean over the past 2500 years, where it has established in other parts of the world.

BIOMASs YIELDS. Mean biomass yield is presented for the second and third growing seasons (Fig. 3). Year, accession, and a year by accession interaction were all significant $(P<0.05)$. In 2012, dry mass (DM) yields ranged from 5.91 to $42.55 \mathrm{Mg} \cdot \mathrm{ha}^{-1}$. All accessions showed an increase in DM yields in 2013, with yields ranging from 6.52 to $64.70 \mathrm{Mg} \cdot \mathrm{ha}^{-1}$. Yields also significantly varied between accessions with 2010-162, 2010-174, and 2009-128 providing the highest yields $(P<0.05$; Fig. 3). Previous studies using accession 2008-209 found similar (Palmer et al., 2014) on multiple sites in North Carolina. Kering et al. (2012) also reported similar yields for A. donax grown in Oklahoma. However, in our study several other accessions had substantially higher yields than 2008-209.

While there was only limited, genetic variability among our A. donax accessions, we obtained wide variation in DM yields. Interestingly, the highest yielding accessions (2010-162, 2010174 , and 2009-128) showed a high level of genetic similarity in the cluster analysis (Fig. 1), suggesting mutations relating to enhanced yield. As these accessions were relatively geographically disparate when collected, it remains unclear if mutations for enhanced yield occurred independently or before the dispersal of clonal material. It is also possible that the wide range of biomass yield could be attributed to epigenetic modifications. Chromatin modification, DNA methylation, small RNAs, and cis-/trans-acting regulatory interactions can generate nonadditive expression patterns as well as ecological, physiological, and morphological novelty (Osborn et al., 2003; Soltis et al., 2014). This phenomenon has been observed for a phenotypically diverse clonally propagated collection of plantain that had limited genetic diversity but a higher degree of cysteine methylation (Noyer et al., 2005). Epigenetic modifications are particularly common in high-level polyploids as genomes need to reconcile multiple copies of genes with redundant functions (Chen, 2007).

The results from this study help to characterize the genetic and cytological diversity of Arundo species and to identify distinct high-biomass-yielding genotypes and phenotypes of A. donax. Although there was limited genetic diversity found among accessions, particularly within plants collected within the United States, there was substantial variation in biomass yields. The lack of fertility of this species limits the ability of crop improvement through conventional breeding approaches. However, while genetic variation measured using ISSR 
markers remains low, plants exhibit wide variation for biomass yield.

\section{Literature Cited}

Ahmad, R., P.S. Liow, D. Spencer, and M. Jasieniuk. 2008. Molecular evidence for a single genetic clone of invasive Arundo donax in the United States. Aquat. Bot. 88:113-120.

Angelini, L., L. Ceccarini, N. Nassi o Di Nasso, and E. Bonari. 2009. Comparison of Arundo donax L. and Miscanthus xgiganteus in a long-term field experiment in central Italy: Analysis of productive characteristics and energy balance. Biomass Bioenergy 33:635-643.

Barker, N.P., H.P. Linder, and E.H. Harley. 1999. Sequences of the grass-specific insert in the chloroplast $\mathrm{rpoC2}$ gene elucidate generic relationships of the Arundinoideae (Poaceae). Syst. Bot. 23:327-350.

Bell, G. 1997. Ecology and management of Arundo donax, and approaches to riparian habitat restoration in southern California, p. 103-113. In: J. Brock, M. Wade, P. Pysek, and D. Green (eds.). Plant invasions: Studies from North America and Europe. Backhuys Publishers, Leiden, The Netherlands.

Bucci, A., E. Cassani, M. Landoni, E. Cantaluppi, and R. Pilu. 2013. Analysis of chromosome number and speculations on the origin of Arundo donax L. (giant reed). Cytol. Genet. 47:237-241.

Chen, Z.J. 2007. Genetic and epigenetic mechanisms for gene expression and phenotypic variation in plant polyploids. Annu. Rev. Plant Biol. 58:377-406.

Christopher, I. and A. Abraham. 1971. Studies on the cytology and phylogeny of South Indian Bambusoideae, Oryzoideae, Arundinoideae, and Festucoideae. Cytology 36:579-594.

Connor, H.E. and M.I. Dawson. 1993. Evolution of reproduction in Lamprothyrsus (Arundineae: Gramineae). Ann. Mo. Bot. Gard. 80:512-517. Cosentino, S., V. Copani, G. D'Agosta, E. Sanzone, and M. Mantineo. 2006. First results on evaluation of Arundo donax L. clones collected in southern Italy. Ind. Crops Prod. 23:212-222.

Don, R.H., P.T. Cox, B.J. Wainwright, K. Baker, and J.S. Mattick. 1991. 'Touchdown' PCR to circumvent spurious priming during gene amplification. Nucleic Acids Res. 19:4008.

Dudley, T. 2000. Arundo donax, p. 53-58. In: C. Bossard, J. Randall, and M. Hoshovsky (eds.). Invasive plants of Calfornia's wildlands. Univ. of California Press, Berkeley, CA.

Gilbert, R., J. Ferrell, and Z. Helsel. 2008. Production of giant reedgrass for biofuel. EDIS Publ. SS AGR 318. 1 May 2015. $<$ http://edis.ifas.ufl.edu/ag327>.

Haddadchi, A., C.L. Gross, and M. Fatemi. 2013. The expansion of sterile Arundo donax (Poaceae) in southeastern Australia is accompanied by genotypic variation. Aquat. Bot. 104:153-161.

Hardion, L., R. Verlaque, A. Baumel, M. Juin, and B. Vita. 2012. Revised systematics of Mediterranean Arundo (Poaceae) based on AFLP fingerprints and morphology. Taxon 61:1217-1226.

Hardion, L., R. Verlaque, A. Fridlender, and B. Vita. 2011. IAPT/ IOPB chromosome data 11. Taxon 60:1221-1223.

Hardion, L., R. Verlaque, A. Fridlender, B. Zehzad, and B. Vita. 2013. IAPT/IOPB chromosome data 15. Taxon 62:1075.

Hardion, L., R. Verlaque, M. Rosato, J.A. Roselló, and B. Vila. 2015. Impact of polyploidy on fertility of Mediterranean Arundo L. (Poaceae). C. R. Biol. 338:298-306.

Hardion, L., R. Verlaque, K. Saltonstall, A. Leriche, and B. Vita. 2014. Origin of the invasive Arundo donax (Poaceae): A trans-Asian expedition in herberia. Ann. Bot. (Lond.) 114:455-462.

Hecker, K.H. and K.H. Roux. 1996. High and low annealing temperatures increase both specificity and yield in touchdown and stepdown PCR. Biotechniques 20:478-485.
Johnson, M., T. Dudley, and C. Burns. 2006. Seed production in Arundo donax? California Invasive Plant Council 14:12-13.

Kao, K.N. 1975. A nuclear staining method for protoplasts, p. 60-64. In: O.L. Gamborg and L.Z. Wetter (eds.). Plant tissue culture methods. Natl. Res. Council Canada, Prairie Regional Lab. Saskatoon, SK, Canada.

Kering, M.K., T.J. Butler, J.T. Biermacher, and J.A. Guretzky. 2012. Biomass yield and nutrient removal rates of perennial grasses under nitrogen fertilization. BioEnergy Res. 5:61-70.

Khudamrongsawat, J., R. Tayyar, and J. Holt. 2004. Genetic diversity of giant reed (Arundo donax) in the Santa Ana River, California. Weed Sci. 52:395-405.

Les, D. and C. Philbrick. 1993. Studies of hybridization and chromosome number variation in aquatic angiosperms: Evolutionary implications. Aquat. Bot. 44:181-228.

Lewandowski, I., J. Scurlock, E. Lindvall, and M. Christou. 2003. The development and current status of perennial rhizomatous grasses as energy crops in the US and Europe. Biomass Bioenergy 25:335-361.

Mariani, C., R. Cabrini, A. Danin, P. Piffanelli, A. Fricano, S. Gomarasca, M. Dicandilo, F. Grassi, and C. Soave. 2010. Origin, diffusion and reproduction of the giant reed (Arundo donax L.): A promising weedy energy crop. Ann. Appl. Biol. 157:191-202.

National Oceanic and Atmospheric Administration. 2010. 1981-2010 Normals. 10 Mar. 2016. <http://www.ncdc.noaa.gov/cdo-web/ datatools/normals $>$.

Nei, M. and W.H. Li. 1979. Mathematical model for studying genetic variation in terms of restriction endocleases. Proc. Natl. Acad. Sci. USA 76:5269-5273.

Noyer, J.L., S. Causse, K. Tomekpe, A. Bouet, and F.C. Baurens. 2005. A new image of plantain diversity assessed by SSR, AFLP and MSAP markers. Genetica 124:61-69.

Osborn, T.C., J.C. Pires, J.A. Birchler, D.L. Auger, J.Z. Chen, H. Lee, and L. Comai. 2003. Understanding mechanisms of novel gene expression in polyploids. Trends Genet. 19:141-147.

Palmer, I.E., R.J. Gehl, T.G. Ranney, D. Touchell, and N. George. 2014. Biomass yield, nitrogen response, and nutrient uptake of perennial bioenergy grasses in North Carolina. Biomass Bioenergy 63:218-228.

Parisod, C., R. Holderegger, and C. Brochmann. 2010. Evolutionary consequences of autopolyploidy. New Phytol. 186:5-17.

Perdue, R.E. 1958. Arundo donax-Source of musical reeds and industrial cellulose. Econ. Bot. 12:368-404.

Pilu, R., E. Cassani, M. Landoni, F.C. Badone, A. Passera, W. Cantaluppi, L. Corno, and F. Adani. 2014. Genetic characterization of an italian giant read (Arundo donax L.) clones collection: Exploiting clonal selection. Euphytica 196:169-181.

Polunin, O. and A. Huxley. 1987. Flowers of the Mediterranean. Hogarth Press, London, UK

Rohlf, F.J. 1989. NTSYS-PC numerical taxonomy and multivariate analysis system. Exeter, New York, NY.

Schönswetter, P. and A. Tribsch. 2005. Vicariance and dispersal in the alpine perennial Bupleurum stellatum L. (Apiacese). Taxon 54:725-732.

Soltis, D.E., C.J. Visger, and P.S. Soltis. 2014. The polyploidy revolution then and now: Stebbins revisited. Amer. J. Bot. 101:1057-1078.

Thompson, J. and R. Lumaret. 1992. The evolutionary dynamics of polyploidy plants: Origins, establishment and persistence. Trends Ecol. Evol. 7:302-307.

Vollmer, K., C. Rainbolt, and J. Ferrel. 2008. Giant reed (Arundo donax): Biology, identification and management. EDIS Publication SS AGR 301. 1 May 2015. <http://edis.ifas.ufl.edu/ag307>. 